Gemma Santiago Alonso

UDK 821.134.2.09"19":305-055.2

Facultad de Filosofía y Letras

DOI: 10.4312/vestnik.13.333-348

Universidad de Ljubljana

Eslovenia

gemma.santiago@ff.uni-lj.si

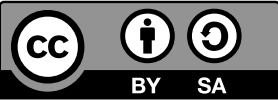

\title{
EL VIAJE EN BUSCA DE SU IDENTIDAD FEMENINA EN HISTORIA DE JAVA DE ELISABETH MULDER Y «SI ESTO ES LA VIDA, YO SOY CAPERUCITA ROJA» DE LUISA VALENZUELA
}

El viaje, en esencia, siempre ha respondido a la necesidad humana de salir a la búsqueda de esa nueva experiencia que cambie la percepción del mundo: se trata, ante todo, de una invitación a sumergirse por caminos imbricados que ayuden a entender el pasado y a transgredirlo, de traspasar el abismo y habitar el otro lado. En esa exploración de lo nuevo se circunscribe la meta fundamental del viaje en sí, esto es, la búsqueda de la identidad y de la mirada y el encuentro con la otredad.

Esta búsqueda inherente en el ser humano ha tenido su reflejo dentro de la literatura universal en el tópico literario del homo viator, cuyos orígenes se pueden rastrear tanto en las odiseas de los héroes grecolatinos en su deseo de conquista de la inmortalidad como, dentro ya de la literatura española, en peregrinos caballeros andantes o desterrados (como el Amadís de Gaula, el Cid Campeador en el Cantar de mio Cid o Quijote en El ingenioso hidalgo Don Quijote de la Mancha) que mostraron tanto el camino tortuoso recorrido y el descubrimiento de lugares recónditos como el deseo del regreso al paraíso perdido. No obstante, tanto los viajeros de antaño como todos los que han ido protagonizando viajes literarios hasta la época actual tienen en común la forma en la que se afronta el viaje: como una búsqueda ambiciosa de la propia identidad cifrado en una suerte de viajero «de naturaleza líquida y fluctuante» (Posada 2019: 428). El periplo emprendido por todos los protagonistas literarios transita caminos que nada tienen que ver con el viaje lineal, pues se trata, como afirma Posada (ibid.), de caminos dispersos que responden a «un movimiento circular, líquido y fluctuante, descentrado y sin itinerarios». Este motivo literario tan recurrido a lo largo de la historia de la literatura es lo que Bajtin (1989: 250) pasó a denominar el cronotopo del camino, es decir, una unidad estructural espacio-temporal narrativa.

En el canon de la literatura de viajes, el hombre viajero «se convierte en héroe, que trasciende espacios, que supera límites físicos, impuestos por la propia naturaleza, y 
límites culturales, establecidos por la sociedad de la cual forma parte» (Marcillas 2012: 221). De esta manera, se consolidó una relación desigual en la que el héroe masculino por excelencia, Ulises, asumió el rol de viajero explorador mientras que la heroína femenina, Penélope, quedó enclaustrada en el espacio privado/doméstico, condenada a la espera. Condicionadas por este patrón heredado, hasta el siglo XX, las contribuciones literarias de las escritoras a la literatura de viajes ${ }^{1}$ fueron escasas en comparación con la de los escritores. Asimismo, el viaje que tiene que emprender la heroína es un recorrido y un camino perteneciente en origen a un mundo masculino, por lo que en su periplo, escritoras y heroínas no han salido a ese viaje iniciático de descubrimiento (relacionado con el viaje del héroe), sino que han conformado un peregrinaje íntimo e interior de redescubrimiento de su identidad individual y social tanto en el espacio privado como, sobre todo, en el espacio público: la heroína cruza y recorre el abismo para reencontrar su esencia que o bien había olvidado o bien había tenido que esconder por su condición de mujer. En su gran epopeya, la mujer ha de tomar conciencia del viaje para poder decidir su destino y habitar en libertad el nuevo espacio rehabitado. El viaje de la mujer transmuta a una peregrinación interior y solitaria que «representa una oportunidad para redefinir o reinventar la propia personalidad» a través de «un ejercicio de introspección [...] que permite construir un nuevo ser personal y social, una identidad basada en la dialéctica sujeto/otro» (Casasole 2013: 251).

Por lo tanto, en este desconocido viaje de la heroína, se accede a una perspectiva femenina en la que, a través de la aventura, el recorrido muestra un perfil que va más allá de ser el dulce ángel del hogar, trascendiendo a un nuevo espacio que transita como sujeto autónomo y en movimiento en el que consigue desprenderse de la piel de Penélope (y con ello, de los modelos de comportamiento femeninos de sumisión y dependencia) y desmontar las diferentes convenciones y constreñimientos a los que se supeditó, con una actitud de resistencia y transgresión ante los códigos patriarcales. Se trata, como sostiene Casasole (2013: 251), de «un proceso de emancipación capaz de dar vida a un sujeto nuevo, que adquiere una nueva identidad social e individual». En todo este proceso, la mujer escritora tendrá la ingente tarea de resignificar el cronotopo del camino hasta hacerlo suyo:

Hace tanto, ya, que venimos lentamente escribiendo, cada vez con más furia, con más autorreconocimiento. Mujeres en la dura tarea de construir con un material signado por el otro. Construir no partiendo de la nada, que sería más fácil, sino transgrediendo las barreras, rompiendo los cánones en busca de esa voz propia $[\ldots]$.

(Valenzuela 2002: 41-42)

1 Véase Marcillas Piquer (2012) para una revisión pormenorizada de las aportaciones de escritoras al cronotopo del camino. 
Por todo lo anterior, el objetivo del presente trabajo se centra en la resemantización del cronotopo del camino en el caso del viaje de la heroína como búsqueda de la identidad femenina, tomando como ejemplos, a modo de ilustración, la Historia de Java de Elisabeth Mulder y el cuento de Luisa Valenzuela «Si esto es la vida, yo soy Caperucita Roja». Para ello, nos serviremos tanto de las reflexiones de las propias autoras (Mulder 1979 y Valenzuela 2002) como de las investigaciones de Cassole (2013), Mañas Martínez (1988, 2006), Díaz (1996), Marković (2013), Martínez (2001), Medeiros- Lichem (2007), Muñoz (1996), Noguerol (2001), Prada (2018), Zapico (2015) y Zipes (2006) entre otros.

\section{2}

\section{ELISABETH MULDER Y LA HISTORIA DE JAVA (1935)}

Mujer indómita desde la juventud, a los 26 años, tras quedarse viuda, experimentará una profunda transformación personal que se verá reflejada en su producción narrativa; su extensa carrera como narradora empezará justo en esta etapa con dos obras esenciales: Una sombra entre las dos (1934) y La historia de Java (1935). Los temas principales que reivindicará en estas dos obras se centran en la búsqueda de la propia identidad (una identidad siempre amenazada), la conquista de la independencia y el tema de la soledad en relación con el arduo deseo de libertad incondicional y de respeto al espacio personal.

Para nuestro trabajo, nos hemos centrado en Historia de Java como ejemplo significativo para la resignificación del cronotopo del camino. Mulder elegirá como protagonista una gata como una forma alegórica de acercarse al tema de la búsqueda de la identidad amenazada de la mujer. A diferencia de Una sombra entre los dos, obra narrativa de tesis feminista en la que la protagonista a lo largo de la novela se empeña en reconquistar y recuperar su auténtica identidad y con la que Mulder irrumpió en la sociedad conservadora española de 1934 con el modelo de una nueva mujer, una nueva Eva, con Historia de Java va un paso más allá y bajo la piel felina de la protagonista se esconde una reflexión más abstracta que en la obra anterior sobre el anhelo de libertad y la reafirmación de la propia identidad, pues como Mulder confesara en una entrevista (1979): «El sentido de la independencia y las formas de libertad están en cada uno de mis libros».

Prada (2018: XXXIII) plantea la obra como «una intransigente parábola sobre la libertad que no admite concesiones». A lo largo del viaje y del camino que emprende la protagonista, Mulder ha ido enmarcando los pasos de Java en una atmósfera muchas veces asfixiante que conmina de manera reiterada la identidad de la gata, así como su excelso sentido de libertad. Ya desde la cita de Paul Géraldy con la que se inicia la historia («Un espíritu verdaderamente superior no está nunca enteramente dominado por el amor $\left.{ }^{2} \gg\right)$, la autora establece el desenlace de la novela: estamos ante el viaje vital y

2 «Un esprit vraiment supérieur n'est jamais tout à fait dominé par l'amour». 
absoluto de la protagonista (con un espíritu indoblegable y superior), que tendrá como brújula durante su periplo los valores de independencia y libertad en estado puro y que desarrollará una concepción moderna del amor, supeditado éste al anhelo de libertad por encima de todo. Mañas Martínez (1988: 274) ve en el personaje de Java a una gata que a lo largo de la historia «adquiere un valor simbólico y mítico» y que es capaz de liberarse de las trabas sociales. Para Mulder: «Java es el mito del intento del deseo y de su realización a costa de la libertad del espíritu humano [...]. Es una obra inactual, intemporal [...] [cuyo] personaje es extremadamente difícil porque es una especie de encrucijada entre lo puramente real, lo puramente poético y lo simplemente de análisis imaginativo» (Mulder, 1979).

Desde el principio de la historia, Java aparece como un ser ingobernable, una gata salvaje «nacida en un bosque» $\left(11^{3}\right)$, de «carácter hermético y desdeñoso» (8), cuyo nombre la mecía «en nostalgias y deseos misteriosos», a quien le «dolía el corazón de avidez de vientos, de ansia de soledades» y que se vio obligada a ocultar «su fiebre de libertad» bajo un «andar fluídico» (10). Desafiada por las constricciones sociales a las que se ve expuesta desde su nacimiento, «la gata enamorada de las estrellas, de las soledades y de los vientos» ha de huir a los bosques cuando los miembros de la sociedad que la rodean intentan domesticarla al límite de «imponerle el amor» (11). Y es justo esta intimidación a su identidad lo que le otorga a la protagonista «una fuerza nueva» que se desata en «una sensación de embriaguez» cuando se descuelga de una rama que le conducirá al camino, al viaje liberador presentado por la autora como su destino, como «el Signo» (12). Una vez superada la encrucijada y haber salido al encuentro con la naturaleza, la gata «quedó convertida en una especie de leyenda» (13), adquiriendo de esta manera lo que Mañas Martínez (1988: 272) denomina «una aureola mítica de gata salvaje». A pesar de que Java experimenta la opción de conocer/convivir en la sociedad, se ve empujada a escapar de ella pues siente menoscabada su propia identidad, y se lanza a los caminos de regreso a la naturaleza para reencontrarse con su esencia salvaje. El contacto con la naturaleza le devolverá la «paz de cuerpo y de espíritu, bebiendo la dulzura de las grandes soledades» (13) y la reconquista de su identidad a través de un viaje interior en el que tomará conciencia de su singularidad gracias a esa fusión con la naturaleza y a su anhelada soledad. A lo largo de este viaje líquido de caminos diseminados y sin itinerarios preconcebidos, Java va y viene de la naturaleza a la sociedad donde gatos domesticados y sumisos buscaban «a la sirena $[\ldots]$ que en el aire que venía del bosque les había hecho confidencias voluptuosas» (14). La heroína felina se dejaba caer en todos estos juegos amorosos de pasiones que dominaba por completo y que, a pesar de que también se pudiera ver obligada a lidiar con el fruto de estas relaciones fugaces, al final siempre acababa abandonando a sus hijos (como ya ocurriera con sus padres) una vez les había enseñado a valerse por

3 La primera edición de Historia de Java es de 1935. La versión que manejamos para este análisis es la del año 2018 e indicamos en las citas sacadas del libro solo la página de dicha edición. 
sí mismos. Así, «Java volvía pronto a ella misma, con el fervor de las estrellas, las soledades y los vientos alisándole el dorso ondulante que el amor había erizado» (14). Sin embargo, como destaca Mañanas Martínez (1988: 230), las situaciones más eróticas en la Historia de Java se consiguen desde la autoafirmación de la identidad y libertad y no en los encuentros amorosos (que Java vive como auténticas batallas campales). Estos supuestos encuentros sexuales adquieren erotismo justo cuando Java vuelve a reencontrarse con su soledad: «Java partía despacio y, oliendo el aire que tenía acres efluvios a sangre, o se echaba sobre el lomo replegaba las patas y se tendía con el vientre a la luna» (14).

En su peregrinaje, Java muestra como con cada uno de sus reencuentros con la naturaleza adquiere una fuerza nueva, y en esa fusión completa con el paisaje que ella experimenta en su odisea, encuentra no solo un refugio sino un espacio íntimo en el que se expande, reafirmando su voz propia en una especie de exaltación y transfiguración. La experimentación y el descubrimiento de la naturaleza en sus reiterados reencuentros la llevan a un extrañamiento, asombro y obnubilación ante el reencuentro con su propio paraíso, en el que aprende a desplegar su recobrada esencia como cuando empieza a sentir el deseo de escapar durante la noche cuando todavía vivía como una gata doméstica («Esperando miraba de noche las estrellas y espiaba las sombras con sus ojos nictálopes que herían la oscuridad como las llamitas de las luciérnagas. Le dolía el corazón de avidez de vientos, de ansia de soledades» [10].) o la primera vez que Java contempla el mar desde lo alto de un acantilado:

Subía de abajo una voz ronca y estallante que no tenía la dislocada ondulación del viento sino una cadencia monótona y mesurada. Pero era una voz llena de sugerencias y de apasionantes temblores.

$[\ldots]$

Le parecía que el monstruo de la voz grave iba a atacarla de un momento a otro, y avanzaba con precaución, dispuesta a saltar al primer contacto y a defenderse. Pero según se acercaba a la voz honda, ésta se hacía más insinuante, más acariciadora su ronca monotonía, y de pronto, al tocar la playa, Java cesó de tener miedo y sintió que el aire salitroso, que la suavidad de la arena, que la voz del invisible monstruo la llenaba de una exultante alegría, de un gozo que corría por ella en oleadas calientes y embriagantes (23).

Al tratarse de una novela de aprendizaje, a pesar de las trampas en las que cae repetidas veces en su vagar errante de la naturaleza a la sociedad y de la sociedad a la naturaleza, terminará entendiendo que la amistad con los humanos le atrae pero le daña, ya que ésta desafía su esencia al dejar de ser ella misma. La naturaleza, por consiguiente, constituye su único refugio: «Y la desilusión, la confianza y la fe perdidas se le fueron enroscando al corazón como serpientes, y medio ahogada, medio ciega, abandonó el bosque, regresó a las cimas, y bebió con humildad la medicina de las grandes soledades» (18). 
Con el transcurrir de los años, su odisea se sumerge en la prueba más dura: el encuentro del amor verdadero con su «corazón errabundo, lleno de violencia y poesía», anhelante de una soledad iluminadora y libertad incondicional (20). A tenor de la cita con la que se abre la novela, Java no puede sintonizarse con el amor por ese componente de domesticación que conlleva, y por la relación que la heroína establece entre el amor y lo socialmente aceptado, relación esta distante de su aspiración de libertad absoluta. Java conoce el amor a través del hombre rubio, «un hombre remoto» a quien ella amaba «por quimérico y [que] él la amaba por ser una criatura de las grandes soledades y más fuertes que él» (22); no obstante, Java terminará renunciando a él debido a que en su viaje ha aprendido que el amor es imposible si no se quiere prescindir de su identidad. A pesar de haber conocido el amor verdadero, su naturaleza salvaje la convierte en esa figura mítica que encumbra la libertad del espíritu humano en su totalidad. En su andadura, aprende a convivir con esta renuncia, por mucho que para Java «la nostalgia no tenía nombre ni contorno moral; era simplemente un dolor sordo, punzante y oscuro, [...][que] le producía angustia [...] o estar prisionera»; además, el «dolor no se veía lenificado por el tiempo, sino que, por el contrario, crecía y se hinchaba como un río nacido muy alto; y el olvido no llegaba nunca a azolvar su corriente» (31). Este discernimiento entre amor e identidad le lleva de nuevo a Java a refugiarse en la naturaleza, «embriagándose en las cimas, bebiendo el licor de las grandes soledades», mientras que el hombre rubio, al comprender que Java había renunciado al amor, acabó aceptándolo y «amándola cada vez más por la continuidad de su fuerza» (34).

En el otoño de su vida, Java se nos muestra fiel al «signo de las cimas, de las estrellas y de los vientos» pues es, ante todo, «una criatura de las grandes soledades» (35), un espíritu superior que ha reconquistado en su odisea su identidad amenazada y ha experimentado una transfiguración que la convierte en una fuerza salvaje de la naturaleza, en una «fuerza mítica del destino» (Mañas Martínez 2006: 272). Esta reafirmación de la identidad personal y conquista de la libertad de la que se apodera Java le conduce a una soledad que fusiona su esencia con su anhelo vital por encima de los intentos de desintegración y amenaza que sufre durante su viaje en sus sucesivos contactos con la sociedad (y, por ende, con la amistad y el amor). Y es, en el fondo, este sentido de amenaza de identidad el motor y eje estructurador del viaje iniciático e íntimo, facilitador de la propia reflexión existencial de Java y de donde surgirá la búsqueda y reconquista de una identidad propia, única y mítica en un espacio de libertad reconquistado y habitado hasta sus últimas consecuencias.

\section{3}

\section{LUISA VALENZUELA Y «SI ESTO ES LA VIDA, YO SOY CAPERUCITA ROJA»}

Para nuestro estudio hemos escogido el cuento « $\mathrm{Si}$ esto es la vida, yo soy $\mathrm{Ca}-$ perucita Roja», que forma parte de la colección de cuentos de hadas Cuentos de 
Hades $^{4}$, donde ya desde el título se distingue el juego de palabras con el parónimo hadas/Hades en clara referencia a tradición (hadas)/ transgresión (Hades). En esta obra, la autora se distancia de los cuentos de los principales compiladores que distorsionaron la historia primigenia (como Perrault o Jacob y Wilhelm Grimm ${ }^{5}$ ), buceando hasta el Hades para rescatar y devolver los cuentos a la versión de tradición oral a la que pertenecieron en su origen. En el caso de Caperucita Roja, según Noguerol (2001: 116), podemos rastrear las huellas del primer testimonio escrito de la historia en un texto latino de Egberto de Lieja (1023). Por las diferentes versiones que se han encontrado en el sur de Francia, se puede deducir que la historia gozó de una larga trayectoria en la tradición oral, donde la heroína aparece representada como una niña despierta y astuta, capaz de engañar al lobo. Con su audacia, aprovecha la ocasión para escapar del lobo gracias a la ayuda de unas lavanderas que protegerán a la niña del lobo, provocándole un trágico final. En consecuencia, la historia primigenia se entroncaba con las historias de aprendizaje en el que la astucia de la niña y la ayuda de las mujeres propiciarán un final feliz a la historia. Sin embargo, como describe Noguerol, en versiones posteriores como la del primer compilador, Perrault (XVII), se popularizó la imagen de Caperucita como una niña desobediente que obtendrá un castigo mortal por haberse desligado del camino sugerido por su madre. En cuanto a la versión de los hermanos Grimm (respetuosos con los principios burgueses del siglo XIX), Noguerol sostiene que, a pesar de seguir manteniendo consecuencias negativas por su desobediencia, esta vez aparece un cazador como salvador (sustituyendo a las primitivas lavanderas), generador de un final feliz más apto para la mentalidad infantil que el texto de Perrault.

Cuentos de Hades, pues, aboga por una escritura femenina que, como asevera Regazzoni (2012: 278), va ligada «a una actitud de resistencia y transgresión ante los códigos patriarcales del género y la sexualidad» en la que la autora deconstruye los «modelos de comportamiento femenino de sumisión y dependencia petrificados en los cuentos de hadas tradicionales»». Valenzuela confiesa en una entrevista que ese conjunto de cuentos:

[...] es una relectura [...] donde la mujer recupera su posición quizá amenazadora, a lo menos amenazadora para el status quo. Por eso mismo usé la palabra Hades, y no hadas. Ya sabés, Hades era el dios griego del infierno, y por

4 El año de publicación de la primera edición de los Cuentos de Hades es 1993, y forma parte de un volumen de cuentos que lleva el título de Simetrías. La versión que manejamos es la del año 1997 e indicamos en las citas sacadas del cuento solo la página de nuestra edición.

5 Valenzuela aglutina a todos estos compiladores que se distanciaron de la historia originaria bajo el nombre de «el gran secuestrador, dios de los infiernos» (2002: 190), contra quien se rebela en los Cuentos del Hades. En sus cuentos, plantea un continuo cuestionamiento de lo impuesto por la tradición sociocultural en aras de desacralizar las versiones moralizantes de dichos compiladores en un claro intento de recontextualización de Caperucita Roja. Valenzuela reivindica la versión original oral de aquellas matriarcas que contaron esta historia manteniendo la autonomía e inclinaciones naturales desinhibidas en la mujer y despojándola de la moral androcéntrica de sumisión femenina que fue incorporada más tarde. 
extensión el propio infierno, el Hades, de donde rescaté o a donde devolví, mejor dicho, esos cuentos con moralejas humillantes (Díaz 1996: 50).

Valenzuela es parte integrante de las numerosas reescrituras posmodernas de cuentos de hadas, donde añade una perspectiva de género que rescata a las protagonistas del espacio marginal donde se las redujo. ${ }^{6}$ La escritora se retrotrae a los orígenes de la tradición oral para dar cuenta del porqué de la reescritura de Caperucita:

[...] las historias las contaron primero, oralmente, las ancianas frente al fogón en las noches para distraer del miedo y para aleccionar. Y las viejas, experimentadas ellas, por lógica no podían decirles a las niñas pobres y obligadas a valerse por sí mismas que fueran pacientes y esperaran al príncipe, por más degradado que fuera el príncipe. Entonces creí entender. El viaje de Caperucita es un tránsito, una verdadera travesía que va de la condición de púber a la de abuela. El bosque es en realidad el tiempo a lo largo del cual se van cosechando experiencias (para meterlas en la canastita). Tres instancias de una misma persona, en simultaneidad: Caperucita, su madre y la abuela. ¿Y el lobo? [...] es la representación del inconsciente, la parte oscura de cada ser humano, lo inconfesable y ominoso con lo que debemos enfrentarnos a diario. ¿Cómo puede pretenderse entonces que la mujer adulta sea una persona completa, íntegra, si se la escinde desde chica de su oscuro deseo? ¿Si no puede abrirse camino por su cuenta, si se le inculca de chica que cualquier apartamiento del dogma conduce a la muerte no sólo de sí, conduce al indirecto asesinato de la pobre, indefensa abuelita? (Valenzuela 2002: 188-189).

La odisea de Caperucita Roja narra, en realidad, un viaje al bosque de la vida. La heroína viene caracterizada por una prenda que en teoría ha sido tejida por la abuela como parte de un «legado cultural femenino que la predefine como persona» (Marković 2013: 181) y que se relaciona con el color de la sangre en clara referencia a su incipiente pulsión sexual y al proceso de transformación al que se enfrenta la niña («Hace poco que usa su capita [...], se la ve bien de colorado [...] y de todos modos le guste o no le guste se la pone, sabe dónde empieza la realidad y terminan los caprichos. Lo sabe aunque no quiera: aunque diga que le duele la barriga» [85]). Sin embargo, por boca de la madre sabemos más adelante que lo de «la capita colorada que te tejió la abuelita [...] no era demasiado exacto. Pero estaba implícito. Esa abuela no teje todavía. Aunque capita colorada hay» (85), es decir, la escritora dota a la niña de un objeto simbólico con el que, a pesar de

6 Otras rescrituras posmodernas de Caperucita Roja las encontramos, entre otras, en Angela Carter (The bloody Chamber, 1979), Rosario Ferré (Arroz con leche, 1977), Carmen Martín Gaite (Caperucita en Manhattan, 1989), Ana María Shua (Casa de geishas, 1992), Angélica Gorodicher (Juego de mango, 1988) o María Negronia (Cuento de hadas, 1994). 
formar parte de un legado cultural, la protagonista todavía tiene la opción de construir su propio destino. Zapico (2015: 159) ve en este gesto de Valenzuela una forma de hacer consciente a la niña «tanto de la tradición recibida como de sus represiones, dotándola de la capacidad de desacralizar los símbolos que obstaculizan su crecimiento personal como mujer». Otros objetos simbólicos con los que Valenzuela equipa a Caperucita son la cestita, que irá rellenando con las diferentes experiencias y recuerdos del camino durante su proceso de maduración, o el espejo, en clara alusión a otros cuentos, y gracias al cual será capaz de culminar el proceso de (des)identificación con la imagen de la madre, aceptando la prohibición de su madre y, como sugiere Marković (2013: 187), asumiendo la completa responsabilidad de su propia conducta.

Al inicio del camino está todavía condicionada por el discurso del miedo que le resuena en su vagar errante por el bosque («A mamá la escucho pero no la oigo. Quiero decir, a mamá la oigo pero no la escucho. De lejos como sordina» [86]). Al poco, se ve ante una primera encrucijada (donde hay que evitar «las sendas muy abruptas o giros en el camino del bosque» o precipitarse a los abismos que le «as/gustan» [86]) que resolverá anulando la voz de la madre en favor de sentir el deseo de su propio cuerpo, anhelante de experienciar placer. En este momento, la heroína ha transgredido los límites físicos del mundo civilizado (alejándose de la casita de la madre) y se sumerge en un espacio oscuro, desconocido, amenazante, lleno de lobos (que le hacen «señas a veces obscenas» [87]), árboles exuberantes y frutillas con claras connotaciones sexuales que puede que tengan «un gusto un poco amargo detrás de la dulzura» [87]. Al desobedecer las reglas impuestas por la madre y adentrarse en la oscuridad del bosque, la ahora adolescente se sumerge en una sexualidad incipiente que le «as/gustará» y que tendrá que conquistar fuera de los prejuicios y constricciones del patriarcado.

Caperucita ha de pasar por diferentes pruebas que le van dotando de experiencias que le llevan a su autorrealización, a su plena autonomía, a la conquista de su destino. En el camino, la protagonista se encuentra con muy diferentes tipos de lobos junto a los que va descubriendo su sexualidad y «a la otredad de su cuerpo y su placer» (Martínez 2001: 187) como otra forma de pulsión vital que le ayuda a seguir recorriendo el camino desde distintos espacios («Hay frutas tentadoras por estas latitudes. Muchas al alcance de la mano. Hay hombres como frutas: los hay dulces, sabrosos, jugosos, urticantes. Es cuestión de irlos probando de a poquito» [89]).

En su proceso de maduración, la heroína entiende que la única manera de conquistar su propio destino es a través de la desobediencia ${ }^{7}$ y la búsqueda de su experiencia del camino en forma de frutos que irá recogiendo en su canastilla, a pesar de todos «los lobos» a los que tendrá que ir abandonando:

7 No hay que olvidar que la evolución del ser humano se basa en la desobediencia y la curiosidad, que la mitología ha interpretado a través de historias como las de Pandora, Lilith o Eva. De hecho, Bakucz (2015: 176) encuentra en la desobediencia «un conflicto necesario para lograr la libertad», que en el caso de Caperucita le «lleva directamente a la integración/libertad que al mismo tiempo significa asumir soledad». 
[...] una puede llegar a sentirse muy sola, sobre todo cuando la voz de madre previene contra el lobo y el lobo anda por ahí y a una se la despierta el miedo. [...] Por suerte a veces puede aparecer alguno que desata el nudo. Esa fruta sí que me la como, le pego mi tarascón y a la vez la meto con cuidado en la canasta para dársela a abuela. [90].

La transformación de Caperucita (y de su propia capa roja) va avanzando a medida que asume su sexualidad y se va liberando de la voz de su madre, esto es, de la herencia cultural del patriarcado. No obstante, para conseguir abrazar completamente la otredad, Caperucita tiene que enfrentarse al espejo y deconstruir todas las imágenes que de ahí se reflejan para obtener una nueva imagen «consustanciada» que le ofrece su auténtica esencia: una transfiguración que integra niña/madre/adolescente/mujer adulta. Esta toma de conciencia empodera su identidad hasta saber quién es ella y porqué su madre la arrojó a un bosque que a la misma madre le asustaba: el bosque hay que atravesarlo para llegar al otro lado del espejo y reconquistar la identidad y el sentido de pertenencia.

El hecho es que al retomar el camino encontré [...] uno de esos clásicos espejos. [...] Lo miré fijo, al espejo, desafiándolo, y vi naturalmente el rostro de mi madre. [...] Sólo le sobraba ese rasguño en la frente que yo me había hecho la noche anterior con una rama baja. Eso, y unas arrugas de preocupación, más mías que de ella. Me reí, se rio, nos reímos, me reí de este lado y del otro lado del espejo, todo pareció más libre, más liviano; [...] Ahora madre y yo vamos como tomadas de la mano [...]. Consustanciadas. Ella cree saber, yo avanzo. Ella puede ser la temerosa y yo la temeraria. Total, la madre soy yo y desde mí mandé a mí-niña al bosque. Lo sé, de inmediato lo olvido y esa voz de madre vuelve a llegarme desde afuera. De esta forma hemos avanzado mucho. Yo soy Caperucita. Soy mi propia madre, avanzo hacia la abuela, me acecha el lobo (92-93).

La odisea final de nuestra heroína culmina con la transformación completa de la capa (que ha pasado de «capita colorada» y «capa que está adquiriendo brillos» con un rojo que «se hace radiante al sol de mediodía» a una capa que llora y se desgarra, «bastante raída, remendada» y de la que finalmente solo queda «un trozo de tela que alguna vez fue roja»). Al haber cruzado el bosque y gozado del placer de su sexualidad, entiende que ya ha perdido y dado como legado su caperuza roja, pues es parte de la herencia femenina ancestral que tiene que seguir transmitiéndose de generación en generación.

Con la capa remendada, suelta, corro por el bosque y es como si volara y me siento feliz. Al verme pasar así, alguno de los desprevenidos pega un manotón pretendiendo agarrarme de la capa, pero sólo logra quedarse con un trozo de 
tela que alguna vez fue roja. A mí ya no me importa. La mano no me importa ni me importa mi capa. Sólo quiero correr y desprenderme. Ya nadie se acuerda de mi nombre. Ya habrán salido otras caperucitas por el bosque a juntar sus frutillas. No las culpo. Alguna hasta quizá haya nacido de mí y yo en alguna parte debo de estarle diciendo: nena, niñita hermosa, llévale esta canastita a tu abuela que vive del otro lado del bosque. Pero ten cuidado con el lobo (95).

La consumación del viaje le brinda una sabiduría que le permite reírse del lobo, perder el miedo y reconocer que «el bosque ya no encierra secretos» (96) para ella. Por fin ha llegado a la casa de la abuela habiendo asumido su lado más salvaje y oscuro con naturalidad, habiéndose transmutado en lobo («con los colmillos al aire y la baba chorreándome de las fauces. [...] En el dintel de mi abuela me lamo las heridas, aúllo por lo bajo, me repongo y me recompongo» [96]).

Sin embargo, la metamorfosis absoluta del cuento la protagonizan abuela y nieta, que son ahora lobo, son ahora una («Y cuando abro la boca para mentar su boca que a su vez se va abriendo, acabo por reconocerla. La reconozco, lo reconozco, me reconozco. Y la boca traga y por fin somos una» [97]). En relación a esta metamorfosis, Muñoz (1996: 236) aduce que «es una forma de recobrar el estado primario, aquel en que la sexualidad era una inclinación natural libremente practicada, exenta de control institucionalizado por médicos, pedagogos, y moralistas [...] que tienden a hacer desaparecer el sexo como un secreto prohibido». Esta imagen entronca con la arquetípica imagen del lobo que, como plantea Zipes (2006: 180), representaba la parte salvaje no domesticada del ser humano. Por lo tanto, este final rizomático fusiona todas las otredades (madre/abuela/lobo) con una Caperucita que ha recuperado su esencia natural: por un lado, indómita, instintiva, salvaje y por encima de la domesticación de las convenciones sociales, pero por el otro reconciliada con la racionalidad del patriarcado. La mutación final que experimenta Caperucita Roja la convierte en «un sujeto trasgresor femenino» (Medeiros-Lichem 2007: 9), capaz de generar su propio destino tras el camino del aprendizaje y tras haber celebrado su cuerpo y su sexualidad. Se trata, en definitiva, de un viaje que termina resolviéndose «en una gradual expansión de la conciencia» (Martínez 2001: 186) en la que Caperucita Roja (que ya no tiene más caperuza) ha dejado de ser una niña (un ser incompleto) y ya es capaz de abrazar su propia voz (o la imbricada polifonía de voces que ha ido integrando), una voz con ecos de la sabiduría de sus predecesoras que la convierte en un ser completo y complejo y la reconcilia e integra en una herencia generacional ancestral líquida y fluida. En esta última escena del cuento, ha desaparecido la imagen del héroe patriarcal que salva/oprime a la mujer en aras de mantener un statu quo; a cambio, se dignifica el final del cuento con una heroína que ha reconquistado su camino y asumido/ fusionado su(s) identidad(es) a través de lo que Marković (2013: 189) ha sugerido como «la reapropiación libre de lo salvaje, lo erótico y lo socialmente subversivo por parte de las mujeres que toman la rienda de su destino». 
Al final de su peregrinaje, la niña -que ya ha traspasado el umbral de la pubertad hasta reencontrarse con la ancianidad y «con su propia sombra» (Valenzuela 2002: 188)integra lo racional y lo irracional, cultura y naturaleza, lo salvaje, la sabiduría y la herencia femenina ancestral en

[...] una nueva definición de lo femenino, un nuevo espacio que entreteje luz y sombra, transformando a la niña incapaz y débil del cuento legendario en un sujeto de enunciación que al expresar sus «oscuros deseos», ha deconstruido la ancestral dicotomía y cartografiado su propio territorio. (Medeiros-Lichem 2007: 7)

\section{$4 \quad$ CONCLUSIONES}

A lo largo de este trabajo nos hemos enfocado en el cronotopo del camino de Bajtin, en relación con la diferencia existente entre el viaje del héroe (un viaje iniciático donde ha de superar desafíos y pruebas en el mundo exterior en busca de la construcción y descubrimiento de un nuevo ser en el que convertirse) y el viaje de la heroína (viaje interior en donde el principal reto se basa en la elaboración de su identidad individual y social y el redescubrimiento de lo que siempre ha sido en esencia, pero que o bien ha olvidado o bien ha tenido que esconder). Como consecuencia, existe la necesidad de resemantización del cronotopo del camino en el caso del viaje de la heroína como una búsqueda que conduce al proceso madurativo del (auto)descubrimiento de la identidad como sujeto femenino, distanciándolo de los preceptos del patriarcado. A modo ilustrativo de la resignificación del cronotopo del camino, hemos utilizado los ejemplos de la Historia de Java de Elisabeth Mulder y del cuento de Luisa Valenzuela «Si esto es la vida, yo soy Caperucita Roja», pues, en los dos relatos, el camino se convierte en el eje estructurador y símbolo de vida de ambas heroínas. Las protagonistas desarrollarán a lo largo del camino del bosque su proceso de maduración desde una incipiente inocencia e ingenuidad hasta la toma de conciencia de su destino, que irán adquiriendo en una odisea individual e íntima. Ambas se verán abocadas a transitar dicho camino para ir experimentando una continua lucha contra el statu quo al que se rebelan, transgrediendo así las diferentes estructuras de dominación y despojándose de una identidad impuesta por la herencia del patriarcado (en donde no se reconocen). No obstante, la transgresión no llevará al castigo o a la muerte, sino que mutará en un gesto heroico. Los sucesivos encuentros con el otro y la amenaza de lo desconocido recorren estos dos viajes donde se irán imbricando diferentes voces, que engendrarán finalmente la suya propia en un singular intercambio de otredades. Todo ello culminará con la reapropiación de lo salvaje, lo erótico y lo identitario.

La indómita necesidad de saciar la curiosidad y la continua reflexión y cuestionamiento de lo establecido las llevará a desafiar el poder establecido, deseosas de asumir su libertad y reencontrarse con una soledad elegida y dignificada. Ante las continuas 
amenazas de la auténtica identidad de Java y Caperucita, éstas responderán con rebeldía, transgresión y curiosidad, que son utilizadas por Mulder y Valenzuela como motor de las dos obras, y como motivo para la reflexión existencial y expansión de la conciencia de ambas ante la búsqueda y reconquista de una identidad propia, única y mítica en un espacio de libertad reconquistado y habitado hasta sus últimas consecuencias.

Ambas autoras se valen de la identidad femenina como modo de reestructuración social y, por consecuencia, para el reconocimiento de una nueva identidad femenina, encriptada fuera de los conceptos masculinos y los preceptos del patriarcado. En nuestro estudio nos hemos servido de los dos relatos analizados como ejemplos esclarecedores y representativos de la reapropiación y resignificación del cronotopo del camino y del viaje, que rompe con los cánones en busca de una voz propia.

\section{BIBLIOGRAFÍA}

BAJTIN, Mijáil (1989) El problema de los géneros discursivos. México: Siglo XXI.

BAKUCZ, Dóra (2015) «Y la boca traga y por fin somos una». Dos Caperucitas en la literatura argentina contemporánea. M. Polić-Bobić/G. Matić/A. Huertas Morales (eds.), La literatura argentina del siglo XX: un recuento. Relecturas de la Argentina del siglo XX ficcionalizada. Zagreb: Sveučilište u Zagrebu, 173-184.

CASASOLE, María Elena (2013) Ojos de mujer observan el mundo: la escritura de viaje femenina. Investigaciones Feministas 4, 241-254.

DÍAZ, Gwendolyn (1996) Entrevista con Luisa Valenzuela. G. Díaz/M. I. Lagos (eds.), La palabra en vilo: narrativa de Luisa Valenzuela. Santiago de Chile: Cuarto Propio, 35-52.

MAÑAS MARTÍNEZ, María del Mar (1988) La obra narrativa de Elisabeth Mulder. Tesis doctoral. Madrid: Universidad Complutense. 4 de agosto de 2021. https:// eprints.ucm.es/id/eprint/3943/

MAÑAS MARTÍNEZ, María del Mar (2006) Elisabeth Mulder: Una escritora en la encrucijada entre el modernismo y la modernidad. Arbor: Ciencia, Pensamiento y Cultura 719, 385-397.

MARCILLAS PIQUER, Isabel (2012) Literatura de viajes en clave femenina: los pre-textos de Aurora Bertrana y otras viajeras europeas. Revista de Filología Románica 29(2), 215-231.

MARKOVIĆ, Ana (2013) La identidad femenina y las relaciones de poder en los relatos de Luisa Valenzuela. Tesis Doctoral. Barcelona: Universidad de Barcelona. 4 de agosto de 2021. https://www.tesisenred.net/bitstream/handle/10803/116768/MARKOVIC_TES S.pdf?sequence $=1 \&$ is Allowed $=\mathrm{y}$

MARTÍNEZ, Z. Nelly (2001) Luisa Valenzuela: lectura descolonizadora del cuento de hadas tradicional. Letras femeninas 27(1), 177-200. 
MEDEIROS-LICHEM, María Teresa (2007) Prisma poligonal de la escritura: «Cuentos de Hades» de Luisa Valenzuela. International Conference on Women, Gender and Discourse in Latin America. Livepool: University of Liverpool. 12 de junio de 2021. http://www.cervantesvirtual.com/nd/ark:/59851/bmc0931797

MULDER, Elisabeth (1979) A fondo. 4 de agosto de 2021. https:/www.rtve.es/play/ videos/a-fondo/fondo-elisabeth-mulder/5487768/

MULDER, Elisabeth (2018) Sinfonía en rojo. Prosa y poesía selecta. Madrid: Colección Obra Fundamental.

MUÑOZ, Willy (1996) Luisa Valenzuela y la subversión normativa en los cuentos de hadas: «Si esto es la vida, yo soy Caperucita Roja». G. Díaz/M. I. Lagos (eds.), La palabra en vilo: narrativa de Luisa Valenzuela. Santiago de Chile: Cuarto Propio, 221-246.

NOGUEROL JIMÉNEZ, Francisca (2001) La metamorfosis de Caperucita. S. Mattalía (ed.), Aún y más allá: mujeres y discursos. Caracas: Escultura, 113-122.

POSADA, Adolfo R. (2019) Nomadismo y vidas erráticas en la literatura española postcontemporánea. Pasavento: Revista de Estudios Hispánicos 7(2), 425-444.

PRADA, Juan Manuel de (2018) Introducción en Elisabeth Mulder, Sinfonía en rojo. Prosa y poesía selecta. Madrid: Fundación Banco Santander, XI-L.

REGAZZONI, Susanna (2012) «Lo exótico es el otro, o soy yo». Espacio y tiempo en el relato de viaje: Condesa de Merlín y Luisa Valenzuela. Verba hispánica 20(2), 273-283.

VALENZUELA, Luisa (1997) Simetrías. Barcelona: Plaza Janés.

VALENZUELA, Luisa (2002) Peligrosas palabras. Reflexiones de una escritora. México: Océano.

ZAPICO, Elena (2015) «¿Colorín, colorado?»: Las reescrituras contemporáneas de los cuentos de hadas en la literatura hispánica. Tesis doctoral. Salamanca: Universidad de Salamanca. 4 de agosto de 2021. https://gredos.usal.es/handle/10366/128826 ZIPES, Jack (2006) Fairy tales and the art of subversion. London: Rouledge.

\section{POVZETEK}

\section{PO POTI ISKANJA ŽENSKE IDENTITETE V DELIH ZGODBA O JAVI ELISABETH MU- LDER IN “ČE JE TO ŽIVLJENJE, SEM JAZ RDEČA KAPICA” LUISE VALENZUELE}

S potovanjem se človek odziva na lastno potrebo po iskanju novih izkušenj, ki bi mu pomagale spremeniti dojemanje sveta. Potovanje nas vabi, da se podamo po prepletenih poteh, ki nam bodo pomagale razumeti preteklost in jo prestopiti. Toda $\mathrm{v}$ kanonu popotne književnosti je že vseskozi utrjeno neenako razmerje med moškim junakom (Odisej), ki je prevzel vlogo popotnika in raziskovalca, ter žensko junakinjo (Penelopa), ki je bila, zaprta v zasebnem prostoru, obsojena na čakanje. 
Posledično mora junakinja, kadar se poda na potovanje, kreniti po poti, ki izvorno pripada moškemu in ki tudi vodi skozi njegov svet. Izhodišče tega prispevka je kronotop poti (Bahtin 1989), ki na junakinjinem potovanju, skupaj z uporništvom in radovednostjo, predstavlja temelje za iskanje identitete ženskega subjekta. V delu Historia de Java [Zgodba o Javi 1935] španske pisateljice Elisabeth Mulder in v kratki zgodbi "Si esto es la vida, yo soy Caperucita Roja” [Če je to življenje, sem jaz Rdeča Kapica 1993] argentinske pisateljice Luise Valenzuele bomo pot in potovanje analizirali kot simbolni prostor učenja in odkrivanja ženske identitete junakinje, ki si poskuša prilastiti tradicionalno moški prostor. Med potovanjem (notranjim in zunanjim) junakinji obeh književnih del odkrijeta drugost in se, ob prehajanju skozi gozd življenja, usmerita k lastni emancipaciji. Zadnji del poti ju tako pripelje do samoodkritja nove ženske identitete, osvobojene patriarhalnih zapovedi. V ta namen se bomo oprli tako na razmišljanja obeh avtoric (Mulder 1979 in Valenzuela 2002) kot tudi na različne študije, med drugim: Bakucz (2015), Cassole (2013), Mañas Martínez (1988, 2006), Díaz (1996), Marković (2013), Martínez (2001), Medeiros-Lichem (2007), Muñoz (1996), Noguerol (2001), Prada (2018), Regazzoni (2012), Zapico (2015) in Zipes (20060).

Ključne besede: potovanje, ženska identiteta, Elisabeth Mulder, Luisa Valenzuela, kronotop poti

\section{ABSTRACT}

THE JOURNEY IN SEARCH OF FEMALE IDENTITY IN HISTORIA DE JAVA BY ELISABETH MULDER AND "SI ESTO ES LA VIDA, YO SOY CAPERUCITA ROJA" BY LUISA VALENZUELA

A journey responds to the human need to go out in search of a new experience that changes the perception of the world: it is an invitation to immerse oneself in interwoven paths that help to understand the past and transgress it. But nevertheless, in the canon of travel literature an unequal relationship has been consolidated in which the male hero (Ulysses) assumes the role of the traveling explorer, while the female heroine (Penelope) is confined to private space and condemned to wait. As a result, the journey that the heroine must undertake is a journey and path that originally belonged to a male world. The starting point of this work is the chronotope of the road (Bajtin 1989), together with the ideas of rebellion and curiosity as the backbone of the search for identity as a female subject on the heroine's journey. Using Elisabeth Mulder's Historia de Java (1935) and Luisa Valenzuela's short story "Si esto es la vida, yo soy Caperucita Roja" (1993), the journey and path are analysed as a symbolic place of learning and finding female identity to re-appropriate a space that traditionally belonged to men. During their inner and outer journeys, the heroines of both stories set out to encounter and discover otherness and their emancipation. They explore the forest of life, with the final journey leading them to the self-discovery of a new female identity, decrypted from the precepts of patriarchy. To this end, we will draw on both the reflections of the authors themselves (Mulder 1979 and Valenzuela 2002) and the research of Bacucz (2015), 
Cassole (2013), Mañas Martínez (1988, 2006), Díaz (1996), Marković (2013), Martínez (2001), Medeiros- Lichem (2007), Muñoz (1996), Noguerol (2001), Prada (2018), Regazzoni (2012), Zapico (2015) and Zipes (2006).

Keywords: journey, female identity, Elisabeth Mulder, Luisa Valenzuela, chronotope of the road

\section{RESUMEN}

\section{EL VIAJE EN BUSCA DE SU IDENTIDAD FEMENINA EN HISTORIA DE JAVA DE ELISABETH MULDER Y «SI ESTO ES LA VIDA, YO SOY CAPERUCITA ROJA»DE LUISA VALENZUELA}

El viaje responde a la necesidad humana de salir a la búsqueda de una nueva experiencia que cambie la percepción del mundo: es una invitación a sumergirse por caminos imbricados que ayuden a entender el pasado y a transgredirlo. Sin embargo, en el canon de la literatura de viajes, se ha consolidado una relación desigual en la que el héroe masculino (Ulises) asumió el rol de viajero explorador mientras que la heroína femenina (Penélope) quedó enclaustrada en el espacio privado, condenada a la espera. Como consecuencia, el viaje que tiene que emprender la heroína es un recorrido y un camino perteneciente, en origen, a un mundo masculino. El punto de partida del presente trabajo es el cronotopo del camino (Bajtin 1989), que, junto con la rebeldía y la curiosidad, constituyen el eje vertebrador de la búsqueda de la identidad como sujeto femenino en el viaje de la heroína. A través de la Historia de Java de Elisabeth Mulder y del cuento de Luisa Valenzuela «Si esto es la vida, yo soy caperucita Roja», se analiza el camino y el viaje como un lugar simbólico de aprendizaje y encuentro de la identidad femenina en un intento de reapropiación de un espacio que tradicionalmente ha pertenecido al hombre. Durante el viaje (interior y exterior), las heroínas de ambas historias saldrán al encuentro y descubrimiento de la otredad y de su propia emancipación, explorando el bosque de la vida. El recorrido final las llevará a alcanzar el (auto)descubrimiento de una nueva identidad femenina desencriptada de los preceptos del patriarcado. Para ello, nos serviremos tanto de las reflexiones de las propias autoras (Mulder 1979 y Valenzuela 2002) como de las investigaciones de Bacucz (2015), Cassole (2013), Mañas Martínez (1988, 2006), Díaz (1996), Marković (2013), Martínez (2001), Medeiros- Lichem (2007), Muñoz (1996), Noguerol (2001), Prada (2018), Regazzoni (2012), Zapico (2015) y Zipes (2006).

Palabras clave: viaje, identidad femenina, Elisabeth Mulder, Luisa Valenzuela, cronotopo del camino 